\title{
MALE PSEUDOHERMAPHRODITISM DUE TO 5 ALPHA REDUCTASE-2 DEFICIENCY-AN UNCOMMON ETIOLOGY
}

\author{
M A MANNAN ${ }^{1}$, MUHAMMAD HAFIZUR RAHMAN², MIRZA AZIZUL HOQUE
}

\begin{abstract}
:
A 15 years adolescent male muslim presented to us with ambiguous genitalia. At birth he was identified as a female baby and since then reared as a female. At the age of 13, his parents surprisingly observed that some of his phenotypic expressions were becoming male type such as deepening of voice, appearance of facial hair, enlargement of phallus, non development of breast and failure to start menstruation. On examination, he had ambiguous genitalia with enlarged phallus with hypospadias, pigmented labioscrotal folds with blind ended vagina, and pubic hair in stage-3. He was diagnosed as a case of pseudovaginal perineoserotal hypospadias. Serum testosterone and LH level were within the normal range. Karyotyping of the patient revealed 46XY. USG of the whole abdomen revealed no mullarian duct derivatives or gonads. Laparoscopic examination showed only one gonad in the left inguinal region. History, physical examination and investigations suggested the diagnosis of male pseudohermaphroditism due to deficiency of 5 alpha reductase- 2 enzyme.
\end{abstract}

Key words: Male pseudohermaphroditism, 5 alpha reductase-2 deficiency.

\section{Introduction:}

Sex determination and differentiation proceed in sequential manner. Genetic sex, determined at the time of fertilization, determines the differentiation of gonads (called gonadal sex) which ultimately leads to the development of internal genital tract and external genitalia and hence the phenotypic sex. The whole process is completed at the time of puberty with the development of secondary sex characteristics. A male psudo hermaphorodite is one whose gonadal tissue is exclusively testis but genital duct or external genitalia or both exhibit incomplete musculinization. Male pseudohermaphroditism can result from deficient testosterone secretion or action, or failure to convert testosterone into more active metabolite dihydrotestosterone (DHT) or its action, or defect in anti-mullerian hormone secretion or action. ${ }^{1}$ Growth of phallus, fusion of labia and formation of scrotum in males require the conversion of testosterone to DHT at tissue level by the enzyme 5 alpha reductase. Testosterone it-self brings about obliteration of the lower part of the vagina, descent of the testis and differentiation of the wolffian duct. Five alpha reductase-2 deficiency $(5 \alpha-\mathrm{RD})$ produces specific clinical features (Table- I). ${ }^{2}$
Table-I

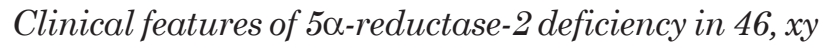
individuals

\begin{tabular}{|c|c|}
\hline Karyotype & $46, \mathrm{XY}$ \\
\hline Inheritance & $\begin{array}{l}\text { Autosomal recessive; mutations in } \\
\text { SRD5A2 gene }\end{array}$ \\
\hline Genitalia & $\begin{array}{l}\text { Usually ambiguous with small, } \\
\text { hypospadiac phallus; blind vaginal } \\
\text { pouch }\end{array}$ \\
\hline $\begin{array}{l}\text { Wolffian duct } \\
\text { derivatives }\end{array}$ & Normal \\
\hline $\begin{array}{l}\text { Müllerian duct } \\
\text { derivatives }\end{array}$ & Absent \\
\hline Gonads & Normal testes \\
\hline Habitus & $\begin{array}{l}\text { Decreased facial and body hair, } \mathrm{r} \\
\text { temporal hair recession, prostate } \mathrm{n} \\
\text { palpable }\end{array}$ \\
\hline
\end{tabular}

Hormone profile Decreased ratio of $5 \alpha / 5 \alpha \mathrm{C}_{21}$ - and $\mathrm{C}_{19}$-steroids in urine; increased $\mathrm{T} /$ $\mathrm{DHT}$ ratio before and after $\mathrm{hCG}$ stimulation; modest increase in plasma LH; decreased conversion of $\mathrm{T}$ to DHT in vitro

$D H T$, dihydrotestosterone; hCG, human chorionic gonadotropin; LH, luteinizing hormone; T, testosterone.

1. Professor, Department of Endocrinology, Dhaka Medical College, Dhaka

2. Assistant Professor, Department of Endocrinology, Dhaka Medical College, Dhaka

3. Associate Professor, Department of Endocrinology, Dhaka Medical College, Dhaka

Correspondence: Dr. M A Mannan, Department of Endocrinology, Dhaka Medical College and Hospital, Dhaka-1000, Bangladesh. E-mail: drmadem@yahoo.com 
Although overall frequencies of this disorder in various countries are not established, increased frequency is reported in the Dominican Republic, some highland tribes in New Guinea, and in Turkey. The high frequency in these areas represents the effect of consanguinity in specific kindreds. ${ }^{3}$ Its prevalence in Bangladesh is not known. As a rare disorder, we report this unusual but interesting case.

\section{Case Report:}

A 15 years old adolescent male muslim child of consanguineous parents presented to us with ambiguous genitalia. At birth he was recognized as a female baby. Until 13 years of age he was reared as a female child. At that time, his parents were surprised to observe that his phallus was gradually increasing in size and urinary flow was under the root of phallus. His musculature and body habitus was becoming male type. His voice became deepened. His breast did not develop (Fig.-1) and his menstruation was not established. On general examination, male musculinizing body habitus was found. His height was $150 \mathrm{~cm}$, weight was $41 \mathrm{~kg}$, BMI was $18 \mathrm{~kg} / \mathrm{m}^{2}$, arm span was $153 \mathrm{~cm}$, upper segment was $76 \mathrm{~cm}$ and lower segment was $74 \mathrm{~cm}$. His skin condition was normal. Thyroid gland was not enlarged. Few facial

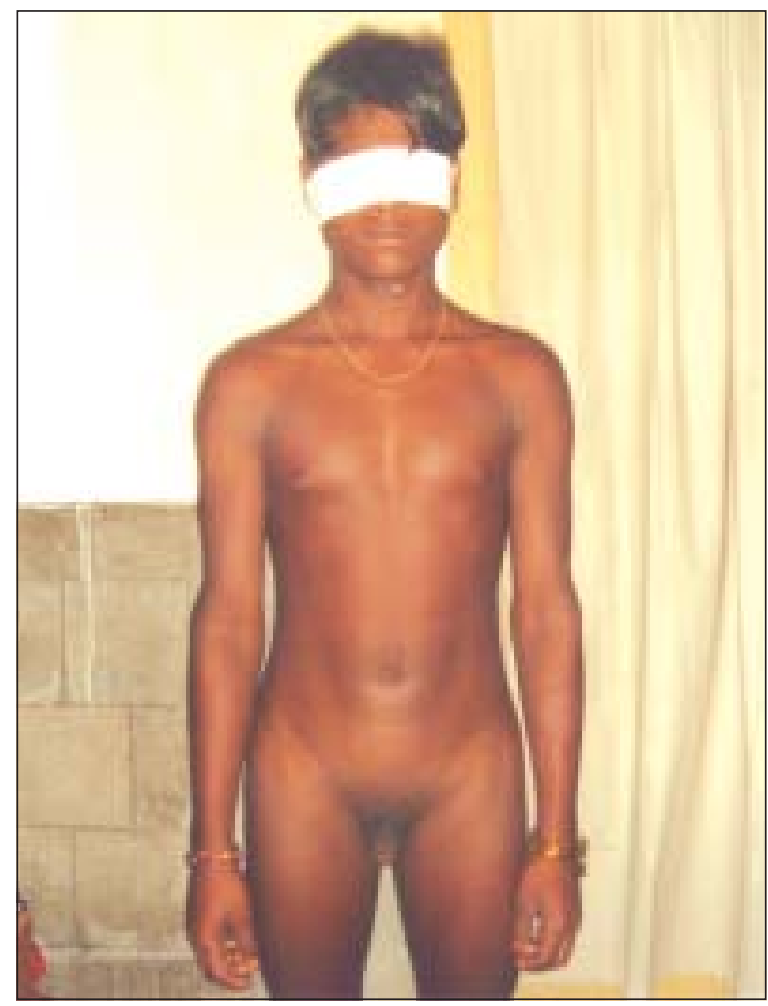

Fig.-1: Showing absence of breast development. hairs were seen in upper lip, breast was in stage-1 and voice of low pitched male type. Local examination found ambiguous genitalia, enlarged phallus with hypospadias, stretch penile length $5 \mathrm{~cm}$, penile diameter $1.5 \mathrm{~cm}$, pigmented bifid scrotum, blind ended vagina and urethral opening in a vestibule under the root of penis (Fig.-2). His pubic hair was in stage3. Gonads were not palpable in the inguinal or scrotal region. Investigations revealed normal complete blood count, random blood glucose- $5.0 \mathrm{mmol} / \mathrm{L}$, S.creatinine$0.7 \mathrm{mg} / \mathrm{dl}$, S.urea- $23 \mathrm{mg} / \mathrm{dl}$ and urine for R/E-normal. Chest $\mathrm{x}$-ray and ECG were normal. Serum electrolytes were: $\mathrm{Na}^{+}-141 \mathrm{mmol} / \mathrm{L}, \mathrm{K}^{+}-4 \mathrm{mmol} / \mathrm{L}$, Chloride-104 $\mathrm{mmo} / \mathrm{L}$, and $\mathrm{TCO}_{2}-25 \mathrm{mmol} / \mathrm{L}$. His karyotype was 46XY. S. testosterone level was $6.3 \mathrm{ng} / \mathrm{ml}$ (normal for male) and S. estradiol $334 \mathrm{pg} / \mathrm{ml}$ (normal for male). USG of whole abdomen revealed no uterus or gonads. Laparoscopic finding revealed one gonad on left side, but no uterus, ovaries or fallopian tubes. S. ACTH

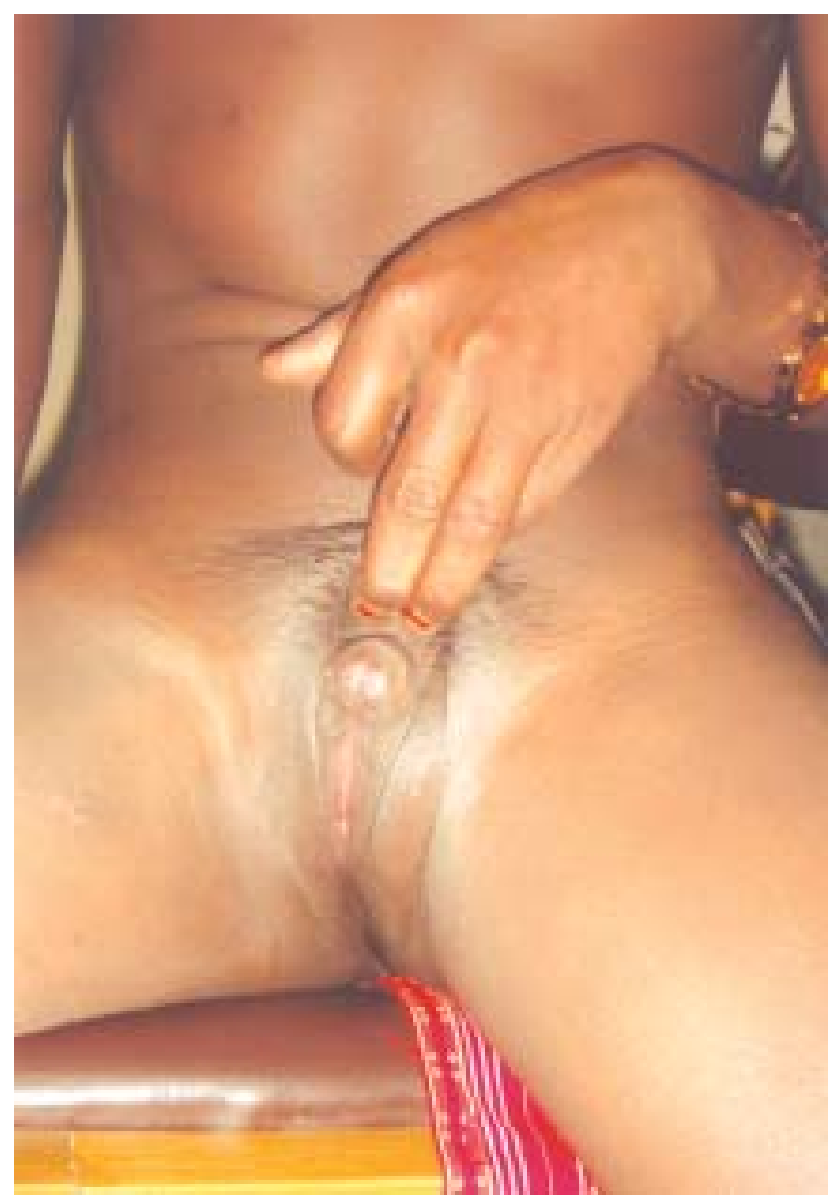

Fig.-2: Showing enlarged phallus with pseudovaginal perineoserotal hypospadias. 
level was $40 \mathrm{pg} / \mathrm{ml}$ (normal). S. LH level was 4.6 munit/ $\mathrm{ml}$ (normal) and S. FSH was $8.12 \mathrm{munit} / \mathrm{ml}$ (normal). S. $\mathrm{T}_{3} \mathrm{~T}_{4}$ and TSH level were within normal range. 17-hydroxy Progesterone was within normal range.

\section{Discussion:}

The condition $5 \alpha-\mathrm{RD}$, an autosomal recessive sexlimited condition, since it only affects genetic males, results from inability to convert testosterone to more physiologically active DHT. ${ }^{3}$ As DHT is required for normal masculinization of the external genitalia in utero, genetic males with $5 \alpha-\mathrm{RD}$ are borne with ambiguous genitalia. ${ }^{3,4}$ Phenotypically their presentation range from infertility with normal male genital anatomy to underdeveloped male with hypospadias to predominantly female external genitalia, most often with mild clitoromegaly. ${ }^{3}$ The most severely affected patients at birth are manifested by a small clitoris-like hypospadiac phallus, a bifid scrotum, a urogenital sinus opening into the perineum and a blind vaginal pouch behind the urethral orifice. 1,2 The uterus and fallopian tubes are absent due to normal secretion of the anti-mullerian hormone. The testes are well differentiated and are located in the inguinal canal or the labioscrotal folds. The wolffian structures (epididymis, vas deferens and seminal vesicles) are well differentiated. Male internal ducts are present but terminate either in a blind pseudovaginal pouch or on the perineum. ${ }^{1-3,5} \mathrm{~A}$ hypoplastic prostate is present. ${ }^{2,3}$ Affected males virilize to a variable degree at puberty. The voice deepens, muscle mass increases, phallus enlarges, libido ensues and penile erections occur. ${ }^{1,6,7}$ The bifid scrotum becomes rugated and pigmented, and the testes enlarge and descend into the labioscrotal folds. None of the postpubertal affected males have acne, more than sparce facial or body hair, temporal hair recession, or enlargement of the prostate, and they do not develop gynecomastia. ${ }^{1,2}$ Spermatogenesis is either absent or profoundly impaired, probably secondary to the cryptorchidism. ${ }^{8}$

There are two microsomal $5 \alpha$-reductase isoenzymes. 6,9 The type 1 isoenzyme is expressed at birth in the liver and nongenital skin. This expression persists in the liver throughout postnatal life, but decreases in skin to unremarkable levels after 2 to 3 years of age and remains low until puberty, when it is again present in nongenital skin. ${ }^{9}$ The type 2 isoenzyme is expressed predominantly in the primordial of the prostate and external genitalia before their differentiation. ${ }^{10}$ Lack of type 2 isoenzyme in the utero during the critical period of male sex differentiation results in incomplete masculinization of urogenital sinus and external genitalia, while testosterone dependent wolffian structures are normally developed. At puberty, plasma testosterone level increase into the adult male range and is converted into DHT (at disproportionately low but measurable range) in peripheral tissues by the expression of the type 1 enzyme in nongenital skin and liver. ${ }^{2}$ So there is marked virilization with increased phallic growth and other signs of masculinization at puberty. Estrogen and androgen synthesis demonstrate normal male androgen and estrogen production; this explains the lack of gynocamastia postpubertally in these patients. ${ }^{2}$ Most of the reported females with male pseudohermaphroditism due to $5 \alpha-\mathrm{RD}$ worldwide changed to male social sex at puberty or beyond. $5,11-$ ${ }^{13}$ So male pseudohermaphroditism due to deficiency of type $25 \alpha$-reductase is the cause of sexual ambiguity of our case. In our patient, we found ambiguous genitalia at birth, perineoscrotal hypospadias, blind vaginal pouch, masculinization at puberty and male karyotype 46XY but did not find gynaecomastia. Though he was reared as female since birth, ultrasound and laparoscopic investigations did not find uterus or fallopian tubes, but one gonad was present in the left inguinal area. Similar features are also found in male pseudohermaphroditism due to $17 \beta$-hydroxysteroid dehydrogenase-3 (17 $\beta$-HSD3) deficiency and partial androgen insensitivity (PAI). But gynaecomastia is usually present in these two conditions. Serum testosterone level is low in 17 $\beta$-HSD3 deficiency and normal or high in PAI and $5 \alpha-\mathrm{RD}$. But serum LH is high in 17 $\beta$-HSD3 deficiency and PAI and normal or mildly raised in $5 \alpha$-RD. Serum DHT level is normal in PAI and low in $5 \alpha-R D$. Similarly serum sex hormone binding globulin fall following androgen therapy in $5 \alpha-R D$ but not in PAI. Serum testosterone and LH level were normal in our case. Due to financial constraints and nonavailability of laboratory facilities serum DHT was not done. All the features suggested this as a case of male pseudohermaphrodite due to $5 \alpha-\mathrm{RD}$. There is evidence that DHT therapy administered prior to puberty may increase penile size but DHT therapy is ineffective once puberty starts. ${ }^{2,3}$ Most males virilize adequately for normal sexual function without replacement. But some recommend supraphysiological doses of testosterone, because this high dose results in normal DHT level and partial 
masculinization; the conversion to DHT is mediated by the type 1 5á-reductase isoenzyme. ${ }^{1,2}$ We started injection testosterone in relatively high dose. He was advised to report after 3 months to see change of phallic growth and sex hormone binding globulin level. He was also advised repair of hypospadias after optimal growth of phallus. This patient may be helped to lead a near normal life if periodically supervised for pubertal progress. Appropriate psychological support for the child and family is also important. The guardian of the patient was given complete information about the diagnosis including, but not limited to, the chromosomal make-up of the individual, the presence of testes, and the medical and surgical options available.

\section{References:}

1. Conte FA, Grumbach MM. Disorders of Sexual Determination \& Differentiation. In: Greenspan FS \& Garner DG, eds. Basic \& Clinical Endocrinology. $8^{\text {th }}$ ed. New York: Lange Medical Books/McGrawHill; 2007:562-610.

2. Grumbach MM, Hughes IA, Conte FA. Disorders of Sex Differentiation. In: Larsen PR et al., eds. Williams Textbook of Endocrinology. $10^{\text {th }}$ ed. Philadelphia: Saunders; 2002:842-1002.

3. Wilson BE. 5-Alpha-Reductase Deficiency, [Online]. Available at: http://emedicine.medscape.com/ article/924291-overview Aaccessed 06 June 2009.

4. Hochberg Z, Chayen R, Reiss N, et al. Clinical, biochemical, and genetic findings in a large pedigree of male and female patients with 5 alpha-reductase 2 deficiency. J Clin Endocrinol Metab 1996; 81: 2821 7.

5. Menodonca BB, Inacio M, Costa EM, et al. Male pseudohermaphroditism due to steroid 5 alphareductase 2 deficiency. Diagnosis, psychological evaluation, and management. Medicine (Baltimore) 1996; 75: 64-76.

6. Griffin JE, McPaul MJ, Russel SW, Wilson JD. The androgen resistance syndromes: Steroid 5áreductase 2 deficiency, testicular feminization, and related disorders. In: Scriver CR et al, eds. The Metabolic and Molecular Basis of Inherited Disease. $8^{\text {th }}$ ed. New York: McGraw Hill; 2001:4117-4146.

7. Wilson JD, Griffin JE, Russell DW. Steroid 5áreductase 2 deficiency. Endocr Rev 2003;14: 577-593.

8. Cai LQ, Fratianni CM, Gautier T, et al. Dihydrotestosterone regulation of semen in male pseudohermaphrodites with 5 alpha-reductase-2 deficiency. J Clin Endocrinol Metab 1994; 79:409414 .

9. Russel DW, Wilson JD. Steroid 5 á-reductase: two genes/two enzymes. Annu Rev Biochem 1994; 63:2561.

10. Siiteri PK, Wilson JD. Testosterone formation and metabolism during male sexual in the human embryo. J Clin Endocrinol Metab 1974; 38:113-125.

11. McGinley J, Peterson RE, Gautier T, et al. Androgens and the evolution of male-gender identity among male pseudohermaphrodites with 5alpha-reductase deficiency. N Engl J Med 1979; 300:1233-7.

12. McGinley J, Miller M, Wilson JD, et al. A cluster of male pseudohermaphrodites with 5 alpha reductase deficiency in Papua New Guinea. Clin Endocrinol 1991; 34:293-5.

13. Akgun S, Ertel NH, McGinley J, et al. Familial male pseudohermaphroditism due to 5 alpha reductase deficiency in a Turkish village. Am J Med 1986; 81: 267-74. 